\title{
Synthesis and photophysical studies of new pyrenylamino acids
}

\author{
Goreti Pereira, ${ }^{a}$ Elisabete M. S. Castanheira, ${ }^{b, *}$ Peter Schellenberg, ${ }^{b}$ M. Belsley, ${ }^{b}$ Paula M. T. Ferreira, ${ }^{a}$ \\ Luís S. Monteiro ${ }^{\mathrm{a}}$ \\ ${ }^{a}$ Centre of Chemistry, University of Minho, Campus de Gualtar, 4710-057 Braga, Portugal. \\ ${ }^{\mathrm{b}}$ Centre of Physics, University of Minho, Campus de Gualtar, 4710-057 Braga, Portugal.
}

\section{ARTICLE INFO}

\section{Article history:}

Received

Received in revised form

Accepted

Available online

\section{Keywords:}

$\beta$-bromodehydroalanines

Pyrenylamino acids

Photophysical studies

Fluorescent probes

\section{ABSTRACT}

Two new pyrenylamino acid derivatives were synthesized from $\beta$-bromodehydroalanine derivatives in good yields using addition and elimination reactions.

The photophysical properties of the two new pyrenylamino acids were studied in several solvents. Steady-state and time-resolved fluorescence measurements revealed that the bipyrenylamino acid undergoes excimer formation, this process being solvent dependent. Rate constants for excimer formation and dissociation were calculated. The monopyrenylamino acid exhibits a photophysical behavior similar to that of pyrene, including the sensitivity to solvent polarity.

The results point to a potential use of these new pyrenyl derivatives as fluorescent probes for peptides and proteins.

\section{Introduction}

Most of fluorescence studies concerning peptides and proteins make use of the natural fluorescent amino acids, tyrosine, tryptophan and phenylalanine. However, the development of new fluorescent non-natural amino acids that can allow selective excitation and detection and act as site specific probes constitutes an important area of research in peptide chemistry. ${ }^{1-3}$

Pyrene has unique photophysical properties, such as high fluorescence quantum yield, long excited-state lifetimes and the ability to form excimers when two pyrene moieties are in close proximity. ${ }^{4,5}$ There are several reports describing the synthesis and applications of pyrenylalanine as a fluorescent probe in peptides and proteins. ${ }^{6-8}$ Previously, we have reported the synthesis of several new pyrenylamino acid derivatives. ${ }^{9,10}$ These compounds were prepared from dehydroamino acid derivatives using several types of reactions, namely Michael additions, substitution reactions and palladium catalyzed crosscouplings. The photophysical properties of some of these compounds showed their potential utility as fluorescence probes for biological systems. ${ }^{9,10}$ Continuing our work concerning the synthesis of non-proteinogenic fluorescent amino acids, we decided to prepare three new pyrenylamino acids using as substrates $\beta, \beta$-disubstituted dehydroalanine derivatives and a strategy previously developed by us. ${ }^{11,12}$ Recently, we described the synthesis of $\alpha$-substituted- $\beta, \beta$ dibromoalanines from a $\beta, \beta$-dibromodehydroalanine by treatment with oxygen nucleophiles and primary amines.
Furthermore, by reacting a $\beta$-bromo- $\beta$-triazolyldehydroalanine with primary amines it was possible to prepare several $\alpha$ amino- $\beta$-iminoalanines. ${ }^{12}$ These compounds afforded the $\alpha$ aminoglycines when treated with silica in dichloromethane. ${ }^{12}$

In this work, this methodology was applied to the synthesis of a $\alpha$-(pyren-1-yl)methylamino- $\beta, \beta$-dibromoalanine, a $\alpha$ (pyren-1-yl)methylamino- $\beta$-iminoalanine and a $\alpha$-(pyren-1yl)methylaminoglycine. The photophysical properties of these compounds were studied in several solvents of different polarity and time-resolved fluorescence studies were performed.

\section{Results and discussion}

The methyl ester of the $N$-tert-butoxycarbonyl- $\beta$, $\beta$ dibromodehydroalanine (1) was treated with pyren-1ylmethanamine hydrochloride in the presence of triethylamine $\left(\mathrm{NEt}_{3}\right)$ in methanol to give the $\alpha$-addition product the methyl 3,3-dibromo-2-(tert-butoxycarbonylamino)-2-[(pyren-1-yl)methylamino)]propanoate $\mathbf{2}$ in $86 \%$ yield (Scheme 1). Compound 1 was obtained from the methyl ester of $\mathrm{N}$-tertbutoxycarbonyldehydroalanine by treatment with $N$ bromosuccinimide (NBS) followed by $\mathrm{NEt}_{3}$. In the ${ }^{1} \mathrm{H}$ NMR spectrum of compound $\mathbf{2}$ it is possible to observe the high chemical shift of the $\beta-\mathrm{CH}$ proton $(6.32 \mathrm{ppm})$ due to the electron-withdrawing effect of the two bromine atoms.

* Corresponding author. Tel.: +351-253604321; fax: +351-253604061; e-mail: ecoutinho@ fisica.uminho.pt 


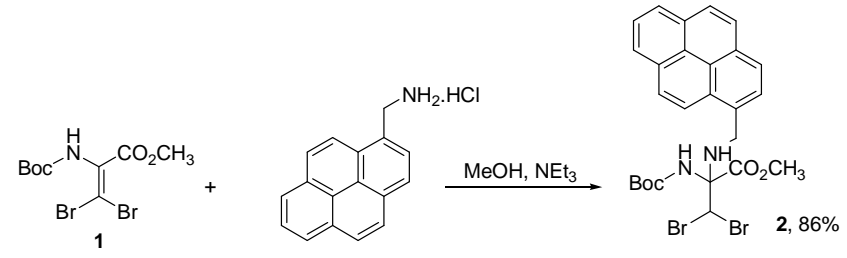

Scheme 1. Synthesis of the methyl 3,3-dibromo-2-(tertbutoxycarbonylamino)-2-[(pyren-1-yl)methylamino]propanoate (2).

The $Z$-isomer of the $\beta$-bromo, $\beta$-triazolyldehydroalanine $(\boldsymbol{Z}$ 3) reacted with pyren-1-ylmethanamine hydrochloride in the presence of $\mathrm{NEt}_{3}$ in methanol to afford the $(E)$-methyl 2-(tertbutoxycarbonylamino)-2-[(pyren-1-yl)methylamino]-3-[(pyren1-yl)methylimino]propanoate (4) (Scheme 2). Compound Z-3 was obtained by a sequential Michael addition reaction between the methyl ester of the $\mathrm{N}$-(4-toluenesulfonyl)- $\mathrm{N}$-(tertbutoxycarbonyl)dehydroalanine and 1,2,4-triazole, followed by halogenation with NBS and $\mathrm{NEt}_{3} .{ }^{12}$ Compound 4 was obtained after $\alpha$-addition, $\beta$-substitution and $\beta$-elimination. The stereochemistry of compound $\mathbf{4}$ was determined by $\mathrm{NOE}$ difference experiments by irradiating the $\beta-\mathrm{CH}$ and observing a $\mathrm{NOE}$ enhancement on the $=\mathrm{NCH}_{2}$ protons. ${ }^{12}$

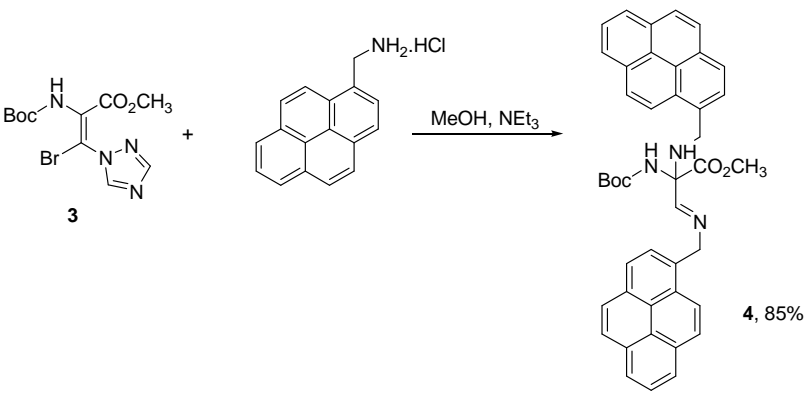

Scheme 2. Synthesis of (E)-methyl 2-(tert-butoxycarbonylamino)-2(pyren-1-ylmethylamino)-3-(pyren-1-ylmethylimino)propanoate (4).

Compound 4 afforded the corresponding methyl 2-(tertbutoxycarbonylamino)-2-[(pyren-1-yl)methylamino]acetate (5) by treatment with silica in dichloromethane (Scheme 3 ). The mechanism proposed for this reaction involves the addition of water to the imine carbon atom followed by elimination of an amide. ${ }^{12}$

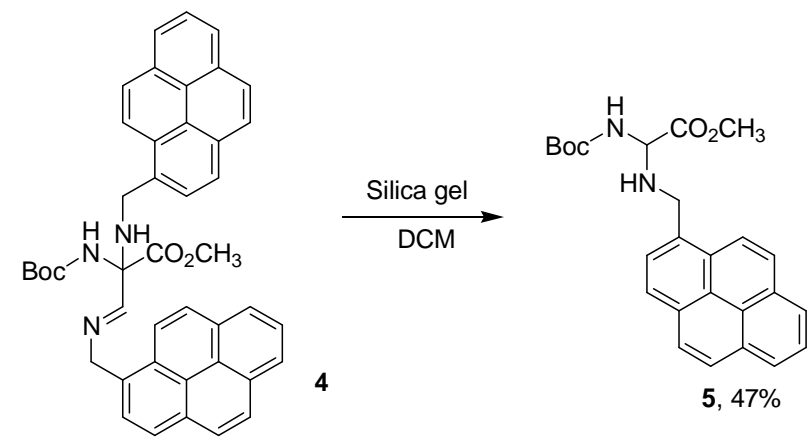

Scheme 3. Synthesis of 2-(tert-butoxycarbonylamino)-2-[(pyren-1yl)methylamino]acetate $(\mathbf{5})$
The photophysical properties of compounds $\mathbf{4}$ and $\mathbf{5}$ were studied in several solvents of different polarity. The maximum absorption $\left(\lambda_{\text {abs }}\right)$ and emission wavelengths $\left(\lambda_{\text {em }}\right)$, molar absorption coefficients $(\varepsilon)$ and fluorescence quantum yields $\left(\Phi_{\mathrm{F}}\right)$ are presented in Table 1 . The normalized absorption and fluorescence spectra of compounds $\mathbf{4}$ and $\mathbf{5}$ are presented in Figures 1 and 2, respectively.

The absorption spectra of compounds $\mathbf{4}$ and $\mathbf{5}$ show intense bands with high molar absorption coefficients at the lowest energy peak $\left(\varepsilon \geq 2 \times 10^{4} \mathrm{M}^{-1} \mathrm{~cm}^{-1}\right.$, Table 1$)$, typical of a $\pi-\pi^{*}$ transition. ${ }^{13}$

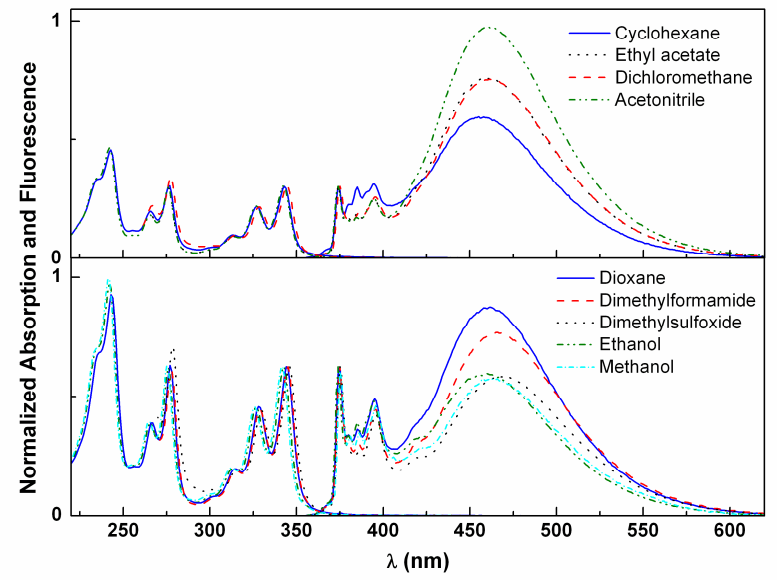

Figure 1. Normalized absorption (in the peak of lowest energy) and fluorescence spectra $\left(\lambda_{\text {exc }}=345 \mathrm{~nm}\right)$ of solutions $\left(1 \times 10^{-5} \mathrm{M}\right.$ for absorption and $1 \times 10^{-6} \mathrm{M}$ for fluorescence) of compound 4 in several solvents.

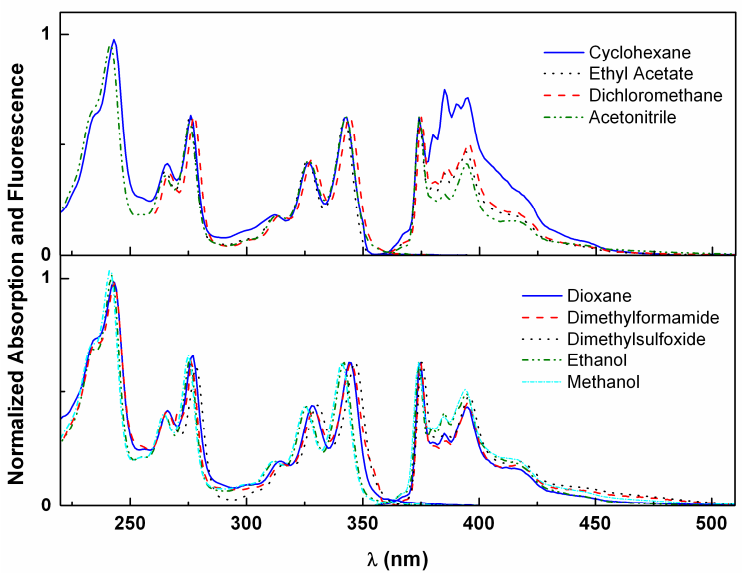

Figure 2. Normalized absorption (in the peak of lowest energy) and fluorescence spectra $\left(\lambda_{\text {exc }}=345 \mathrm{~nm}\right)$ of solutions $\left(1 \times 10^{-5} \mathrm{M}\right.$ for absorption and $1 \times 10^{-6} \mathrm{M}$ for fluorescence) of compound $\mathbf{5}$ in several solvents.

Compound 4 displays a prominent excimer emission band with maximum near $460 \mathrm{~nm}$, in all solvents studied (Figure 1), as this compound possesses two pyrene moieties. The absorption spectra and the emission in the monomer region are roughly similar to those of pyrene. ${ }^{4}$ This is due to the absence of conjugation between the aromatic moieties, caused by the presence of the single bonds linking the pyrenyl groups. A distinct behaviour resulting in the total loss of the vibrational structure of pyrene emission was previously observed for a pyrenylindole ${ }^{10}$ and for pyrene-dimethylaniline derivatives, ${ }^{13,14}$ due to strong charge transfer in the excited state. 
Table 1. Maximum absorption $\left(\lambda_{\text {abs }}\right)$ and emission wavelengths $\left(\lambda_{\mathrm{em}}\right)$, molar absorption coefficients $(\varepsilon)$ and fluorescence quantum yields $\left(\Phi_{\mathrm{F}}\right)$ for compounds 4 and $\mathbf{5}\left(\lambda_{\text {exc }}=345 \mathrm{~nm}\right)$ in several solvents.

\begin{tabular}{|c|c|c|c|c|c|c|}
\hline \multirow[t]{2}{*}{ Solvent } & \multicolumn{2}{|l|}{$\lambda_{\text {abs }} / \mathrm{nm}\left[\varepsilon / 10^{4} \mathrm{~mol}^{-1} \mathrm{dm}^{3} \mathrm{~cm}^{-1}\right]$} & \multicolumn{2}{|l|}{$\lambda_{\mathrm{em}} / \mathrm{nm}$} & \multicolumn{2}{|l|}{$\Phi_{\mathrm{F}}^{[\mathrm{a}]}$} \\
\hline & 4 & 5 & 4 & 5 & 4 & 5 \\
\hline Cyclohexane & $\begin{array}{c}343(6.12) ; 327(4.41) ; 313 \\
(1.99) ; 277(6.15) ; 266(4.00) ; \\
243(9.22)\end{array}$ & $\begin{array}{c}343 \text { (2.94); } 327(1.97) ; 312(0.87) ; \\
276(2.98) ; 265 \text { (2.44); } 243 \text { (4.77); } \\
237 \text { (3.09) sh }\end{array}$ & $\begin{array}{l}374 ; 380 ; 385 \\
390 ; 394 ; 455\end{array}$ & $\begin{array}{c}374 ; 380 ; 385 ; \\
390 ; 395 ; 418 s h\end{array}$ & 0.40 & 0.48 \\
\hline Dioxane & $\begin{array}{l}344(7.50) ; 328(5.48) ; \\
315(2.36) ; 277(7.53) ; \\
267(4.67) ; 243(11.1)\end{array}$ & $\begin{array}{c}344(1.96) ; 328(1.39) ; 315(0.64) \\
277(2.06) ; 266(1.33) ; 243(3.06) ; \\
237(2.33) s h\end{array}$ & $\begin{array}{l}375,385,391 \\
395 ; 458\end{array}$ & $\begin{array}{l}375 ; 380,385 \\
395 ; 415 s h\end{array}$ & 0.45 & 0.31 \\
\hline Ethyl acetate $^{[\mathrm{b}]}$ & $\begin{array}{c}343(5.73) ; 327(4.12) ; 313 \\
(1.76) ; 276(5.62) ; 266(3.46)\end{array}$ & $\begin{array}{c}342(3.18) ; 326(2.20) ; 312(0.93) \\
276(3.22) ; 265(1.96)\end{array}$ & $\begin{array}{l}374 ; 384,393 \\
\quad 414 ; 460\end{array}$ & $\begin{array}{l}374 ; 380 ; 385 \\
394 ; 412 s h\end{array}$ & 0.28 & 0.37 \\
\hline Dichloromethane $\mathrm{e}^{[\mathrm{b}]}$ & $\begin{array}{c}344(8.43) ; 328(6.01) ; 315 \\
(2.68) ; 277(9.44) ; 267(6.18)\end{array}$ & $\begin{array}{c}342(2.79) ; 328(1.94) ; 315(0.80) ; \\
277(2.80) ; 267(1.66)\end{array}$ & $\begin{array}{l}375 ; 386 ; 395 ; \\
\quad 418 ; 457\end{array}$ & $\begin{array}{l}375 ; 380 ; 386 \\
395 ; 412 s h\end{array}$ & 0.52 & 0.56 \\
\hline $\begin{array}{l}N, N- \\
\text { dimethylformamide }{ }^{[\mathrm{b}]}\end{array}$ & $\begin{array}{l}345(7.19) ; 329(5.14) ; 315 \\
(2.19) ; 278(7.05)\end{array}$ & $\begin{array}{c}345(2.53) ; 329(1.71) ; 315(0.75) ; \\
277(2.47)\end{array}$ & $\begin{array}{c}375 ; 386 ; 395 ; \\
466\end{array}$ & $\begin{array}{l}375 ; 380 ; 386 \\
395 ; 416 s h\end{array}$ & 0.23 & 0.22 \\
\hline Acetonitrile & $\begin{array}{c}343(6.17) ; 327(4.41) ; 313 \\
(1.99) ; 276(6.08) ; 266(3.70) ; \\
242(9.49)\end{array}$ & $\begin{array}{c}343(2.39) ; 327(1.64) ; 313(0.68) ; \\
276(2.27) ; 265(1.47) ; 242(3.63) ; \\
234(2.52) s h\end{array}$ & $\begin{array}{l}374 ; 379 ; 385 \\
394 ; 461\end{array}$ & $\begin{array}{l}374 ; 380 ; 385 \\
395 ; 416 s h\end{array}$ & 0.31 & 0.16 \\
\hline Dimethylsulfoxide $^{[b]}$ & $\begin{array}{c}346(9.92) ; 330(4.90) ; 316 \\
(2.23) ; 302(1.26) ; 278(7.79)\end{array}$ & $\begin{aligned} 347(2.98) ; & 330(2.10) ; 317(0.90) ; \\
& 278(2.88)\end{aligned}$ & $\begin{array}{l}375 ; 386 ; 396 ; \\
\quad 419 ; 471\end{array}$ & $\begin{array}{l}375 ; 386 ; 396 ; \\
\quad 417 \text { sh }\end{array}$ & 0.30 & 0.26 \\
\hline Ethanol & $\begin{array}{c}343(6.42) ; 327(4.68) ; 313 \\
(2.04) ; 276(6.39) ; 266(3.98) ; \\
242(10.00)\end{array}$ & $\begin{array}{c}342(3.17) ; 326(2.23) ; 312(1.01) ; \\
276(3.21) ; 265(2.02) ; 242(5.12) ; \\
234(3.47) s h\end{array}$ & $\begin{array}{l}374 ; 379 ; 385 \\
394 ; 416 ; 456\end{array}$ & $\begin{array}{l}374 ; 380 ; 385 \\
394 ; 412 s h\end{array}$ & 0.25 & 0.22 \\
\hline Methanol & $\begin{array}{c}342(4.25) ; 326(3.09) ; 312 \\
(1.36) ; 275(4.27) ; 265(2.69) ; \\
242(6.76)\end{array}$ & $\begin{array}{c}341(2.21) ; 325(1.55) ; 312(0.70) ; \\
275(2.33) ; 264(1.42) ; 241(3.65) ; \\
234(2.51) s h\end{array}$ & $\begin{array}{l}374 ; 379 ; 385 \\
394 ; 418 ; 461\end{array}$ & $\begin{array}{l}374 ; 385 ; 394 \\
\quad 415 \text { sh }\end{array}$ & 0.14 & 0.11 \\
\hline
\end{tabular}

${ }^{\text {[a] }}$ Relative to 9,10-diphenylanthracene in ethanol $\left(\Phi_{\mathrm{F}}=0.95\right) .{ }^{15}$ Error about $10 \%$. ${ }^{[b]}$ Solvents cut-off: dimethylsulfoxide, 270 nm; $N, N$-dimethylformamide, $275 \mathrm{~nm}$; ethyl acetate, $260 \mathrm{~nm}$; dichloromethane, $260 \mathrm{~nm}$. sh: shoulder.

Compound 5 exhibits absorption and emission spectra (Figure 2) that resemble those of pyrene, ${ }^{4}$ with generally high fluorescence quantum yields $\left(\Phi_{\mathrm{F}}=0.58\right.$ for pyrene in cyclohexane). ${ }^{16} \mathrm{~A}$ similar behaviour was observed for the methyl ester of $N, N$-bis(tert-butoxycarbonyl)- $\beta$-[(pyren-1yl)methylamino]alanine, previously synthesized by some of us. ${ }^{9}$

The fluorescence quantum yield values, $\Phi_{\mathrm{F}}$, are very reasonable for both pyrenylamino acids $\mathbf{4}$ and $\mathbf{5}$, but a significant decrease is detected in methanol (Table 1). In this case, solute-solvent hydrogen-bonding interactions may play an important role, leading to an enhance of singlet-triplet intersystem crossing efficiency. ${ }^{17}$ The two pyrenylamino acids have the possibility of establishing hydrogen bonds with several solvents, through NH groups (donors) and ester groups (acceptors) of Boc or acetate moieties. This is also a common behaviour with the previously obtained $N, N$-bis(tertbutoxycarbonyl)- $\beta-[($ pyren-1-yl)methylamino]alanine methyl ester. $^{9}$

For compound 4, the ratio of emission intensities between excimer and monomer, $\mathrm{I}_{\mathrm{E}} / \mathrm{I}_{\mathrm{M}}$ (with $\mathrm{I}_{\mathrm{M}}$ taken in the first vibronic peak of the monomer emission) is solvent dependent (values are presented in Table SD1 in Supplementary Data). Dynamic excimer formation is a diffusion-influenced process and viscosity plays an important role. If the rate of excimer formation is proportional to the diffusion coefficient (and assuming that $D$ is proportional to $1 / \eta)$, the plot of $\ln \left(\mathrm{I}_{\mathrm{E}} / \mathrm{I}_{\mathrm{M}}\right) v$. $\ln \eta$ should be linear. ${ }^{18}$ In fact, this plot is roughly linear with a negative slope, if methanol is not considered (Figure SD1 in Supplementary Data). However, we also need to address the formation of static excimers (excimers originated from preassociated pyrene dimers in the ground state). To predict how pyrene dimers influence the results, the excitation spectra were recorded at $376 \mathrm{~nm}$ (monomer emission) and 480nm (excimer emission), for both compounds 4 and 5 (Figures 3 and 4). As expected, for compound $\mathbf{5}$ no differences are observed in excitation spectra (Figure 4) collected at different wavelengths. For compound 4, some differences are detected (Figure 3), but a clear evidence of pre-associated dimer formation is not obtained from steady-state results. The formation of ground state dimers usually causes a shift between the excitation spectra recorded at different emission wavelengths, as well as changes in the peak-to-valley intensity ratio., ${ }^{5,19}$

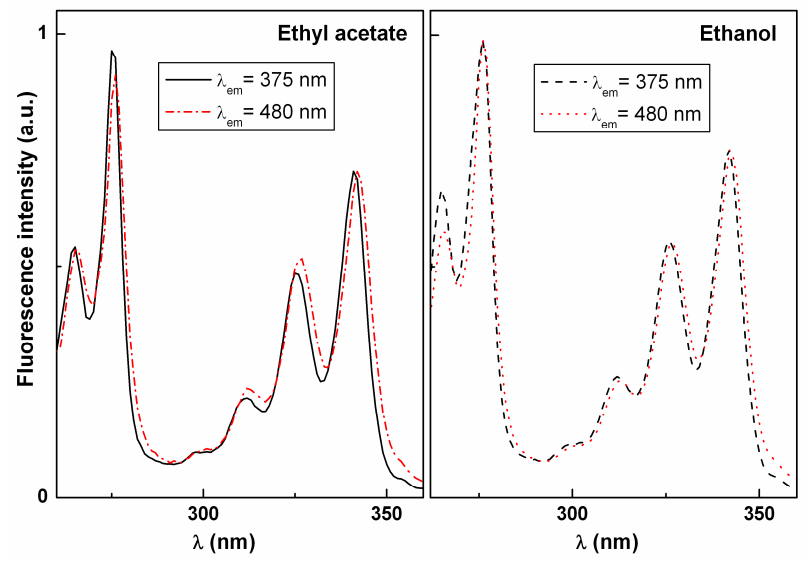

Figure 3. Excitation spectra for compound $\mathbf{4}$ in ethyl acetate and ethanol, as examples. 


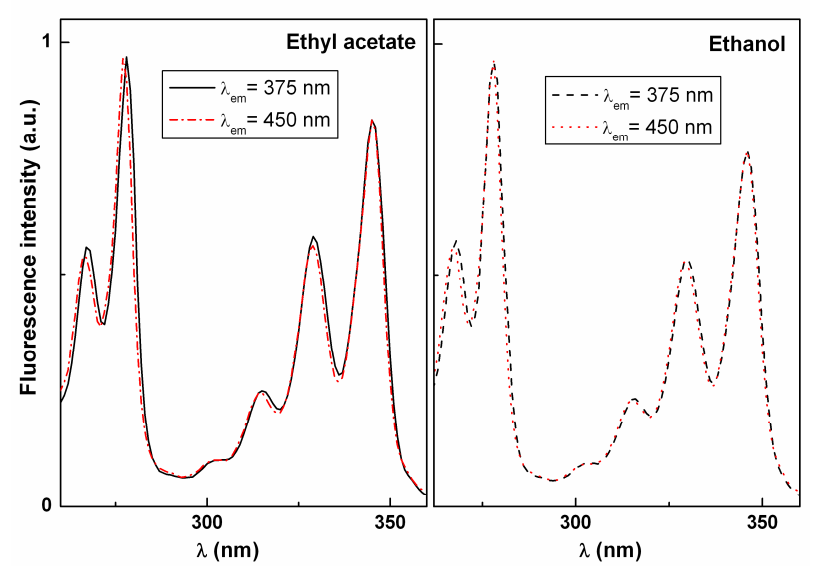

Figure 4. Excitation spectra for compound $\mathbf{5}$ in ethyl acetate and ethanol, as examples.

Time-resolved decays can give more relevant information about the excited-state kinetics of this compound, as described below.

Fluorescence emission of compound $\mathbf{5}$ displays a solvent sensitivity through variations of the relative intensities of the first and third vibronic bands $\left(\mathrm{I}_{1} / \mathrm{I}_{3}\right)$, as already reported for pyrene (the widely used Py scale of solvent polarities). ${ }^{20}$ Table 2 shows the comparison between the intensities ratio $I_{1} / I_{3}$ for pyrene and for the new pyrenylamino acid $\mathbf{5}$. It can be observed that for both molecules the $I_{1} / I_{3}$ values follow the same trend (Figure 5), the values being higher for compound 5, maybe due to the groups directly linked to the pyrene moiety. Therefore, the pyrenylamino acid $\mathbf{5}$ may be useful as polarity probe for peptides and proteins.

Table 2. Ratio of emission intensities between the first and the third vibronic bands, $\mathrm{I}_{1} / \mathrm{I}_{3}$, for pyrene (from reference 20 ) and compound $\mathbf{5}$.

\begin{tabular}{c|c|c}
\hline \multirow{2}{*}{ Solvent } & \multicolumn{2}{|c}{$\mathbf{I}_{\mathbf{1}} / \mathbf{I}_{\mathbf{3}}$} \\
\cline { 2 - 3 } & Pyrene $^{20}$ & Compound 5 \\
\hline Cyclohexane & 0.58 & 0.83 \\
Ethanol & 1.18 & 1.53 \\
Methanol & 1.35 & 1.61 \\
Ethyl acetate & 1.37 & 1.68 \\
Dichloromethane & $-{ }^{[a]}$ & 1.57 \\
Dioxane & 1.50 & 1.98 \\
Acetonitrile & 1.79 & 2.23 \\
$N, N$-Dimethylformamide & 1.81 & 2.25 \\
Dimethylsufoxide & 1.95 & 2.33 \\
\hline
\end{tabular}

${ }^{\text {[a] }} \mathrm{A}$ value of 1.46 is reported for 1,2-dichloroethane. ${ }^{20}$

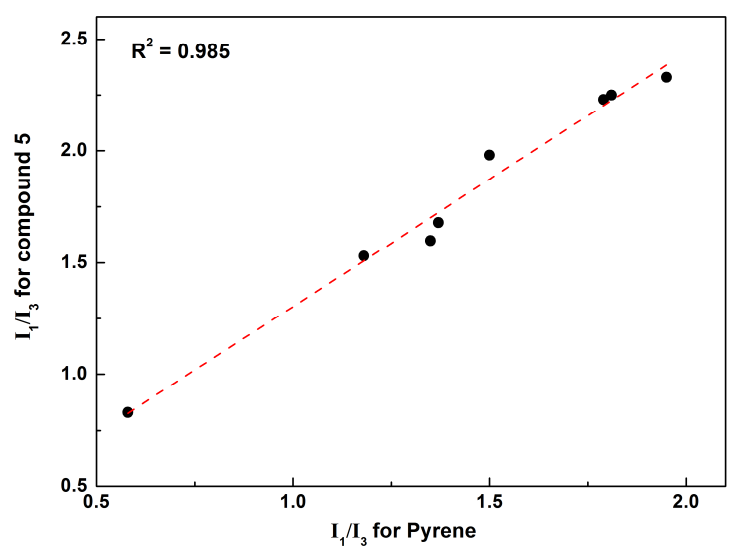

Figure 5 . Correlation between the fluorescence intensities ratio, $I_{1} / I_{3}$, for compound $\mathbf{5}$ and for pyrene.
Lifetime measurements using the single photon counting technique with picosecond resolution were performed for compounds $\mathbf{4}$ and $\mathbf{5}$ in two different solvents (ethanol and ethyl acetate), after deoxygenation by nitrogen bubbling (for 40 minutes). This is important as quenching efficiency is usually different for monomer and excimer emission. In fact, the longer the lifetime in the absence of oxygen, the stronger the sensitivity to the presence of $\mathrm{O}_{2} \cdot{ }^{17,21-23}$ The excitation was performed at $270 \mathrm{~nm}$. Monomer emission was detected at 380 $\mathrm{nm}$ (where no dimeric emission occurs), while excimer emission was measured at $500 \mathrm{~nm}$ (where monomer emission is negligible, see Figure 2). Fluorescence decays of pure pyrene $\left(10^{-6} \mathrm{M}\right)$ in the same solvents were also measured at $\lambda_{\mathrm{em}}=380$ $\mathrm{nm}$, for comparison. Monoexponential decays were obtained in both solvents, with lifetimes of around $160 \mathrm{~ns}$ (ethanol) and 120 ns (ethyl acetate) (Table 3). These lifetimes are significantly lower than those reported for completely degassed solutions $(\tau=410 \mathrm{~ns} \text { for pyrene in ethanol })^{17}$ and can be attributed to the presence of residual oxygen, that could remain even after nitrogen bubbling.

Nevertheless, the pyrene decay in ethyl acetate is faster than in ethanol, may be due to quenching by the carbonyl group of the solvent.

The experimental decay curves of the pyrenylamino acid 5 in both solvents, obtained at $\lambda_{\text {em }}=380 \mathrm{~nm}$, are also monoexponentials (Figure 6), with lifetimes very similar to those of pure pyrene (Table 3 ).

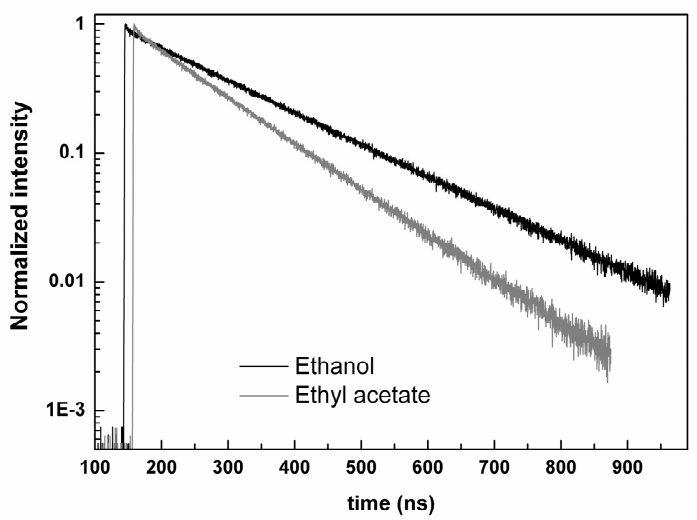

Figure 6. Fluorescence decay curves for the pyrenylamino acid $\mathbf{5}$ in ethanol and ethyl acetate.

This indicates that intrinsic quenching from the carbonyl group of the pyrenylamino acids can be neglected, which is also inferred from the generally high fluorescence quantum yields obtained ( $v d$. Table 1). In fact, in compounds $\mathbf{4}$ and $\mathbf{5}$, the carbonyl group is not directly linked neither conjugated to the pyrenyl moieties, having a low effect in the photophysical behaviour of these pyrenyl derivatives, in contrast to what happens in molecules with aromatic moieties directly linked to carbonyl moieties. ${ }^{24}$

For the bipyrenylamino acid 4, monomer-excimer kinetics must be employed. When only dynamic excimers are present, the classical Birks' scheme (Scheme 4) applies: ${ }^{25}$ 


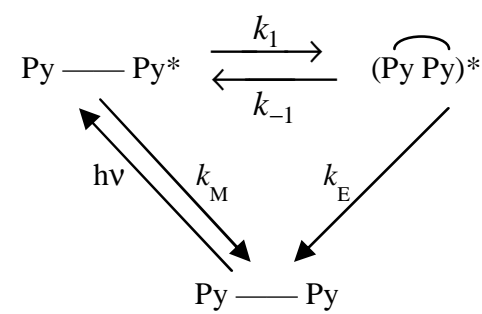

Scheme 4

where $k_{1}$ is the rate constant for excimer formation, $k_{-1}$ is the rate constant for excimer dissociation, and $k_{\mathrm{M}}$ and $k_{\mathrm{E}}$ are the reciprocal lifetimes of the excited monomer and excimer, respectively.

Scheme 4 predicts that, after a $\delta$ pulse of excitation light, the monomer decays as a sum of two exponentials and the excimer as a difference of two exponentials: ${ }^{25}$

$$
\begin{aligned}
& I_{\mathrm{M}}=a_{1} \exp \left(-\lambda_{1} t\right)+a_{2} \exp \left(-\lambda_{2} t\right) \\
& I_{\mathrm{E}}=a_{3} \exp \left(-\lambda_{1} t\right)+a_{4} \exp \left(-\lambda_{2} t\right)
\end{aligned}
$$

where

$$
2 \lambda_{1,2}=\left(A_{\mathrm{x}}+A_{\mathrm{y}}\right) \mp \sqrt{\left(A_{\mathrm{x}}-A_{\mathrm{y}}\right)^{2}+4 k_{1} k_{-1}}
$$

$$
A_{\mathrm{X}}=k_{\mathrm{M}}+k_{1} \quad A_{\mathrm{y}}=k_{\mathrm{E}}+k_{-1}
$$

and

$$
\frac{a_{2}}{a_{1}}=\frac{A_{\mathrm{x}}-\lambda_{1}}{\lambda_{2}-A_{\mathrm{x}}} \quad \frac{a_{4}}{a_{3}}=-1
$$

From the values of the decay constants $\left(\lambda_{1}, \lambda_{2}\right)$ and the ratio $a_{2} / a_{1}$, all the relevant kinetic rate parameters $\left(k_{1}, k_{-1}\right.$, and $\left.k_{\mathrm{E}}\right)$ can be calculated, once the monomer lifetime, $\tau_{\mathrm{M}}=1 / k_{\mathrm{M}}$, is known. The $\tau_{\mathrm{M}}$ values were taken as the lifetimes of the (mono)pyrenylamino acid $\mathbf{5}$ in both solvents (Table 3 ).

The experimental decay curves of compound $\mathbf{4}$ in the excimer emission region $\left(\lambda_{\mathrm{em}}=500 \mathrm{~nm}\right)$ are biexponentials with a risetime (Figure 7A), according to equation (2), showing the formation of dynamic excimers. However, the ratio of preexponential factors, $a_{4} / a_{3}$, deviates significantly from -1 (Table 3 ). This behavior can indicate the presence of pyrene dimers pre-associated in the ground state, absorbing part of the excitation light. In solution, the excited pre-associated dimers can revert quickly to excimers and only the emission of the latter is observed. ${ }^{5}$

In this case, Scheme 4 has to be modified as Scheme 5, that considers the fraction of light, $\alpha$, absorbed by non-associated pyrenyl moieties in the ground state,

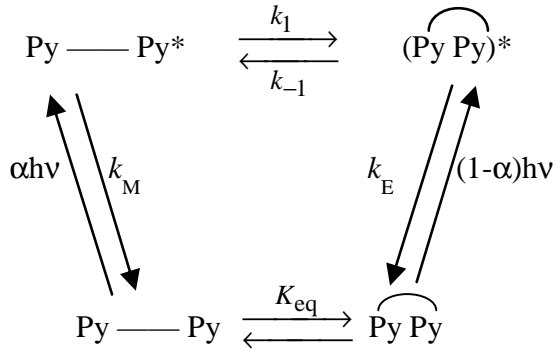

Scheme 5 where $K_{\text {eq }}$ is the equilibrium constant for ground-state dimer formation.

This model was already used to describe the cyclization of polymer chains, both ends labeled with 1-pyrenyl groups. ${ }^{18}$ Scheme 5 predicts that equations (1) to (4) remain valid, ${ }^{26}$ but the ratios of pre-exponential factors are modified, in order to consider the fraction of light absorbed by non-associated chromophores in the ground state, ${ }^{18}$

$$
\begin{gathered}
\frac{a_{2}}{a_{1}}=\frac{\alpha\left(A_{\mathrm{x}}-\lambda_{1}\right)-(1-\alpha) k_{-1}}{\alpha\left(\lambda_{2}-A_{\mathrm{x}}\right)+(1-\alpha) k_{-1}} \\
\frac{a_{4}}{a_{3}}=\frac{(1-\alpha)\left(A_{\mathrm{y}}-\lambda_{1}\right)-\alpha k_{1}}{(1-\alpha)\left(\lambda_{2}-A_{\mathrm{y}}\right)+\alpha k_{1}}
\end{gathered}
$$

The monomer decay curves (Figure 7B) were fitted with a sum of two exponentials, constraining the decay constants to the values recovered from the excimer decay curve fitting. However, only a triexponential curve describes well these monomer decays, the third lifetime (with a very small weight) being similar to that of compound 5 (Table 3). Therefore, this third lifetime corresponds to a small fraction of molecules with only one pyrene moiety. An example of decay curve fitting is shown in Figure SD2 in Supplementary Data.

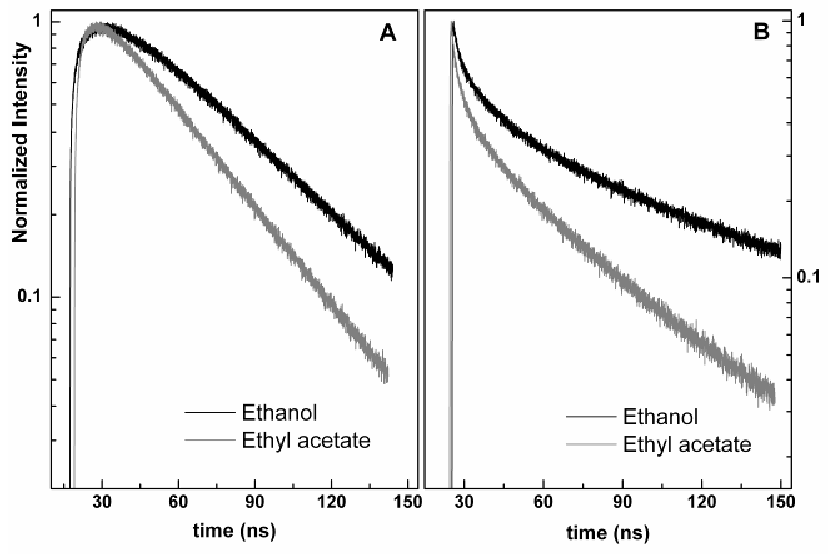

Figure 7. Fluorescence decay curves for the pyrenylamino acid 4 in ethanol and ethyl acetate. A: $\lambda_{\text {em }}=500 \mathrm{~nm} ; \mathrm{B}: \lambda_{\mathrm{em}}=380 \mathrm{~nm}$.

With equations (1)-(4) and (6)-(7), the rate constants for monomer-excimer kinetics for the bipyrenylamino acid $\mathbf{4}$ in both solvents were determined (Table 4). The formation of excimer has a slightly higher rate constant $\left(k_{1}\right)$ for ethyl acetate, which may be mainly due to the lower solvent viscosity $(0.42$ $\mathrm{cP}$ for ethyl acetate and $1.14 \mathrm{cP}$ for ethanol at $\left.25^{\circ} \mathrm{C}\right) .{ }^{27} \mathrm{~A}$ viscosity dependent intramolecular excimer formation was observed for 1,5-bis(1-pyrenylcarboxy)pentane in alkane solvents, ${ }^{28}$ with slightly higher rate constants than those of compound 4 for similar viscosities. ${ }^{28}$ Besides, excimer dissociation $\left(k_{-1}\right)$ and decay $\left(k_{\mathrm{E}}\right)$ rates for this compound are faster in ethanol than in ethyl acetate, both factors justifying the significantly lower $I_{E} / I_{M}$ observed in this alcohol relative to ethyl acetate (Table SD1 in Supplementary Data). 
Table 3. Fluorescence decay times for compounds $\mathbf{4}$ and $\mathbf{5}$ in ethanol and ethyl acetate.

\begin{tabular}{|c|c|c|c|c|c|c|c|}
\hline & Solvent & $a_{1}$ & $\tau_{1}(\mathrm{~ns})$ & $a_{2}$ & $\tau_{2}(\mathrm{~ns})$ & $a_{3}$ & $\tau_{3}(\mathrm{~ns})$ \\
\hline Pyrene & Ethanol & 1 & 166.5 & --- & --- & --- & --- \\
\hline$\left(\lambda_{\mathrm{em}}=380 \mathrm{~nm}\right)$ & Ethyl acetate & 1 & 122.2 & --- & --- & --- & --- \\
\hline Compound $\mathbf{5}$ & Ethanol & 1 & 161.7 & --- & --- & --- & --- \\
\hline$\left(\lambda_{\mathrm{em}}=380 \mathrm{~nm}\right)$ & Ethyl acetate & 1 & 121.8 & --- & --- & --- & --- \\
\hline Compound 4 & Ethanol & 0.58 & 38.47 & -0.42 & 4.46 & --- & --- \\
\hline$\left(\lambda_{\mathrm{em}}=500 \mathrm{~nm}\right)$ & Ethyl acetate & 0.57 & 36.01 & -0.43 & 4.11 & --- & --- \\
\hline Compound 4 & Ethanol & 0.45 & 38.47 (fixed) & 0.53 & 4.46 (fixed) & 0.02 & 201 \\
\hline$\left(\lambda_{\mathrm{em}}=380 \mathrm{~nm}\right)$ & Ethyl acetate & 0.31 & 36.01 (fixed) & 0.66 & 4.11 (fixed) & 0.03 & 172 \\
\hline
\end{tabular}

The fraction of light absorbed by ground-state pyrene dimers $(\alpha)$ is similar in both solvents. As expected, the rate constant for excimer formation in compound $\mathbf{4}$ is $c a$. ten times higher than the observed for the cyclization of polymeric chains both ends labeled with pyrenyl groups. ${ }^{25,29}$

Table 4. Rate constants for excimer formation $\left(k_{1}\right)$ and dissociation $\left(k-_{1}\right)$, excimer reciprocal lifetime $\left(k_{\mathrm{E}}\right)$ and fraction of light, $\alpha$, absorbed by nonassociated pyrenyl groups in ground state, for compound 4.

\begin{tabular}{cccc}
\hline Parameter & Ethanol & Ethyl acetate \\
\hline$k_{1}\left(\mathrm{~s}^{-1}\right)$ & $1.43 \times 10^{8}$ & $1.80 \times 10^{8}$ \\
$k-1\left(\mathrm{~s}^{-1}\right)$ & $6.48 \times 10^{7}$ & $4.92 \times 10^{7}$ \\
$k_{\mathrm{E}}\left(\mathrm{s}^{-1}\right)$ & $3.65 \times 10^{7}$ & $3.31 \times 10^{7}$ \\
$\alpha$ & 0.81 & 0.79 \\
\hline
\end{tabular}

The viscosity dependence of intramolecular excimer formation in 1,3-bis-(1-pyrenyl)propane has been widely used to monitor fluidity changes in microheterogeneous systems, reported by variations in the ratio between excimer and monomer emission intensities. ${ }^{30-35}$ Compound $\mathbf{4}$, due to its ability to be inserted in peptides and proteins, can also be useful to monitor changes in local viscosity in these types of biomolecules.

\section{Conclusions}

New pyrenylamino acids, bearing one and two pyrenyl moieties, were prepared from $\beta$-bromodehydroalanine derivatives by treatment with pyren-1-ylmethanamine.

These compounds exhibit very reasonable fluorescence quantum yields in several solvents and can be useful as fluorescent probes, as they maintain similar photophysical behaviour to that of pyrene (compound 5) or bipyrenyl derivatives (compound 4). The pyrenylamino acid $\mathbf{5}$ exhibits a solvent sensitive emission through variations of the relative intensities of the first and third vibronic bands $\left(I_{1} / I_{3}\right)$, being useful as polarity probe. The bipyrenylamino acid 4, through monomer-excimer kinetics, can be used to monitor microviscosity changes in peptides and proteins.

\section{Experimental section}

General methods: Melting points $\left({ }^{\circ} \mathrm{C}\right)$ were determined in a Gallenkamp apparatus and are uncorrected. ${ }^{1} \mathrm{H}$ and ${ }^{13} \mathrm{C}$ NMR spectra were recorded on a Bruker Avance $\mathrm{II}^{+}$at 400 and 100.6 $\mathrm{MHz}$, respectively. ${ }^{1} \mathrm{H}-{ }^{1} \mathrm{H}$ spin-spin decoupling and DEPT $\theta 45^{\circ}$ were used. Chemical shifts are given in ppm and coupling constants in Hz. MS and HRMS data were recorded by the mass spectrometry service of the University of Vigo, Spain.

The reactions were monitored by thin layer chromatography (TLC). Column chromatography was performed on MachereyNagel silica gel 230-400 mesh. Petroleum ether refers to the boiling range $40-60^{\circ} \mathrm{C}$.

Spectroscopic measurements: Spectroscopic grade solvents, such as cyclohexane, dimethylsulfoxide, dimethylformamide, dioxane, acetonitrile, methanol and ethanol were supplied by Sigma-Aldrich. Dichloromethane and ethyl acetate (for spectroscopy) were purchased from Acros Organics.

Absorption spectra were recorded in a Shimadzu UV-3101PC UV-Vis-NIR spectrophotometer. Fluorescence measurements were performed using a Fluorolog 3 spectrofluorimeter, equipped with double monochromators in both excitation and emission, Glan-Thompson polarizers and a temperature controlled cuvette holder. Bandwidths of $0.5 \mathrm{~nm}$ were used for both excitation and emission. Fluorescence spectra were corrected for the instrumental response of the system.

For fluorescence quantum yield determination, the solutions were previously bubbled for 40 minutes with ultrapure nitrogen. The fluorescence quantum yields $\left(\Phi_{\mathrm{s}}\right)$ were determined using the standard method (equation 8). ${ }^{36,37} 9,10$-Diphenylanthracene in ethanol was used as reference, $\Phi_{\mathrm{r}}=0.95$ at $25^{\circ} \mathrm{C}$. ${ }^{15}$

$\Phi_{\mathrm{S}}=\left\lfloor\left(A_{\mathrm{r}} F_{\mathrm{S}} n_{\mathrm{S}}^{2}\right) /\left(A_{\mathrm{S}} F_{\mathrm{r}} n_{\mathrm{r}}^{2}\right)\right\rfloor \Phi_{\mathrm{r}}$

where $A$ is the absorbance at the excitation wavelength, $F$ the integrated emission area and $n$ the refraction index of the solvents used. Subscripts refer to the reference (r) or sample (s) compound. The absorbance value at excitation wavelength was always less than 0.1 , in order to avoid inner filter effects.

Time resolved fluorescence measurements: The fluorescence decay times were determined using the 3rd harmonics of a Ti:Sa laser, at $270 \mathrm{~nm}$ for excitation. The decay curves were gained by Time Correlated Single Photon Counting (TCSPC) using a Becker \& Hickl SPC-150 computer board collecting the photon detection events from a Hamamatsu MCP R3809U-51 photon counting unit. The pulse width was around $100 \mathrm{fs}$ and the IRF around $20 \mathrm{ps}$. The emission was measured at $380 \mathrm{~nm}$ and at $500 \mathrm{~nm}$. The solutions were bubbled for 40 minutes with ultrapure nitrogen before measurements, to remove dissolved oxygen. Decay curves were analyzed using an iterative reconvolution method based on the algorithm of Marquardt. ${ }^{38}$ 


\section{Synthesis}

Synthesis of compounds $\mathbf{1},{ }^{39}$ and $\mathbf{3}:{ }^{12}$ The synthesis of these compounds was described elsewhere. ${ }^{12,39}$

Synthesis of methyl 3,3-dibromo-2-(tert-butoxycarbonylamino)-2[(pyren-1-yl)methylamino]propanoate 2: To a solution of Boc$\Delta \mathrm{Ala}(\beta-\mathrm{Br}, \beta-\mathrm{Br})-\mathrm{OMe}(0.25 \mathrm{mmol}, 89.7 \mathrm{mg})$ in methanol $(2 \mathrm{~mL})$, 1-pyrenemethylamine hydrochloride (1 equiv.) and $\mathrm{NEt}_{3}(2.2$ equiv.) were added. The reaction mixture was left stirring at room temperature overnight. The reaction mixture was filtered and the solvent removed under reduced pressure to give compound 2 (127 $\mathrm{mg}, 86 \%$ ) as a white solid. M.p. $106.0-107.0^{\circ} \mathrm{C}$ (from ethyl acetate/petroleum ether). ${ }^{1} \mathrm{H}$ NMR (400 $\left.\mathrm{MHz}, \mathrm{CDCl}_{3}\right): \delta=1.55$ (s, $9 \mathrm{H}, \mathrm{CH}_{3}$ Boc), 3.43 (br s, 1H, NH), 3.87 (s, $\left.3 \mathrm{H}, \mathrm{OCH}_{3}\right), 4.38$ (d, $\left.J=12.4 \mathrm{~Hz}, 1 \mathrm{H}, \mathrm{CH}_{2}\right), 4.55\left(\mathrm{~d}, J=12.4 \mathrm{~Hz}, 1 \mathrm{H}, \mathrm{CH}_{2}\right), 6.04$ (br s, $1 \mathrm{H}, \mathrm{NH}), 6.32$ (s, $1 \mathrm{H}, \beta-\mathrm{CH}), 7.99-8.06$ (m, $4 \mathrm{H}, \mathrm{ArH})$, 8.13-8.21 (m, $4 \mathrm{H}, \mathrm{ArH}), 8.49(\mathrm{~d}, J=9.2 \mathrm{~Hz}, 1 \mathrm{H}, \mathrm{ArH}) \mathrm{ppm} .{ }^{13} \mathrm{C}$ NMR $\left(100.6 \mathrm{MHz}, \mathrm{CDCl}_{3}\right): \delta=28.24\left[\mathrm{C}\left(\mathrm{CH}_{3}\right)_{3}\right], 46.50\left(\mathrm{CH}_{2}\right)$, $48.61(\mathrm{CH}), 53.65\left(\mathrm{OCH}_{3}\right), 78.35(\mathrm{C}), 80.97\left[\mathrm{OC}\left(\mathrm{CH}_{3}\right)_{3}\right], 123.61$ $(\mathrm{CH}), 124.70(\mathrm{CH}), 124.74(\mathrm{C}), 124.92(\mathrm{C}), 125.03(\mathrm{CH}), 125.07$ $(\mathrm{CH}), 125.86(\mathrm{CH}), 127.23(\mathrm{CH}), 127.39(\mathrm{CH}), 127.52(\mathrm{CH})$, $127.62(\mathrm{CH}), 129.49(\mathrm{C}), 130.83(\mathrm{C}), 131.25$ (C), $132.24(\mathrm{C})$, $153.68(\mathrm{C}=\mathrm{O}), \quad 168.37 \quad(\mathrm{C}=\mathrm{O})$. HRMS (TOF): Calc. for $\mathrm{C}_{26} \mathrm{H}_{27} \mathrm{Br}_{2} \mathrm{~N}_{2} \mathrm{O}_{4}$ 589.03376; found 589.03321.

Synthesis of (E)-methyl 2-(tert-butoxycarbonylamino)-2-[(pyren-1yl)methylamino]-3-[(pyren-1-yl)methylimino]propanoate 4: To a solution of Boc- $\Delta \mathrm{Ala}(\beta-\mathrm{Br}, \beta$-triazol)-OMe $(0.25 \mathrm{mmol}, 86.8 \mathrm{mg})$ in methanol $(5 \mathrm{~mL})$, 1-pyrenemethylamine hydrochloride $(2.2$ equiv.) and $\mathrm{NEt}_{3}$ (4.4 equiv.) were added. The reaction mixture was left stirring at room temperature overnight. The reaction mixture was filtered and the solvent removed under reduced pressure to give compound 4 (140 mg, 85\%) as a white solid. M.p. $161.0-162.0{ }^{\circ} \mathrm{C}$ (from ethyl acetate/petroleum ether). ${ }^{1} \mathrm{H}$ NMR (400 MHz, $\left.\mathrm{CDCl}_{3}\right): \delta=1.50\left(\mathrm{~s}, 9 \mathrm{H}, \mathrm{CH}_{3} \mathrm{Boc}\right), 3.73(\mathrm{~s}, 3 \mathrm{H}$, $\left.\mathrm{OCH}_{3}\right), 4.08\left(\mathrm{~d}, J=12.8 \mathrm{~Hz}, 1 \mathrm{H}, \mathrm{CH}_{2}\right), 4.38(\mathrm{~d}, J=12.8 \mathrm{~Hz}$, $\left.1 \mathrm{H}, \mathrm{CH}_{2}\right), 5.18\left(\mathrm{~d}, J=15.4 \mathrm{~Hz}, 1 \mathrm{H}, \mathrm{N}=\mathrm{CH}_{2}\right), 5.25(\mathrm{~d}, J=15.4$ $\mathrm{Hz}, 1 \mathrm{H}, \mathrm{N}=\mathrm{CH}_{2}$ ), 6.90 (s, $1 \mathrm{H}, \mathrm{NH}$ ), 7.44 (br s, $\left.1 \mathrm{H}, \beta-\mathrm{CH}\right), 7.61$ (d, $J=7.6 \mathrm{~Hz}, 1 \mathrm{H}, \mathrm{ArH}), 7.73(\mathrm{~d}, J=9.2 \mathrm{~Hz}, 1 \mathrm{H}, \mathrm{ArH}), 7.86$ (d, $J=7.6 \mathrm{~Hz}, 1 \mathrm{H}, \mathrm{ArH}), 7.92-8.10(\mathrm{~m}, 13 \mathrm{H}, \mathrm{ArH}$ and NH$), 8.17$ (d, $J=7.2 \mathrm{~Hz}, 2 \mathrm{H}, \mathrm{ArH}) \mathrm{ppm} .{ }^{13} \mathrm{C} \mathrm{NMR}\left(100.6 \mathrm{MHz}, \mathrm{CDCl}_{3}\right): \delta=$ $28.27\left[\mathrm{C}\left(\mathrm{CH}_{3}\right)_{3}\right], 43.88\left(\mathrm{CH}_{2}\right), 53.25\left(\mathrm{OCH}_{3}\right), 60.00\left(\mathrm{CH}_{2}\right), 75.29$ (C), $80.21\left[\mathrm{OC}\left(\mathrm{CH}_{3}\right)_{3}\right], 122.86(\mathrm{CH}), 123.06(\mathrm{CH}), 124.59(\mathrm{CH})$, $124.67(\mathrm{C}), 124.73$ (C), $124.77(\mathrm{CH}), 124.79$ (C), 124.89 (C), $124.95(\mathrm{CH}), 124.96(\mathrm{CH}), 125.19(\mathrm{CH}), 125.32(\mathrm{CH}), 125.77$ $(\mathrm{CH}), 125.94(\mathrm{CH}), 127.06(\mathrm{CH}), 127.25(\mathrm{CH}), 127.32(\mathrm{CH})$, $127.39(\mathrm{CH}), 127.41(\mathrm{CH}), 127.89(\mathrm{CH}), 128.75(\mathrm{C}), 129.07(\mathrm{C})$, 130.63 (C), 130.64 (C), 130.75 (C), 131.03 (C), 131.20 (C), $131.24(\mathrm{C}), 132.82(\mathrm{C}), 154.48(\mathrm{C}=\mathrm{O}), 159.88(\mathrm{CH}), 169.01$ $(\mathrm{C}=\mathrm{O})$. HRMS (TOF): calcd. for $\mathrm{C}_{43} \mathrm{H}_{38} \mathrm{~N}_{3} \mathrm{O}_{4}$ 660.28623; found 660.28568 .

Synthesis of 2-(tert-butoxycarbonylamino)-2-[(pyren-1yl)methylaminolacetate 5: Compound $4(0.17 \mathrm{mmol}, 114 \mathrm{mg})$ was treated with silica $(1.00 \mathrm{~g})$ in dichloromethane $(5 \mathrm{~mL})$ overnight. Column chromatography, using diethyl ether/petroleum ether $(1: 1)$ afforded compound 5 (34 mg, 47\%) as a white solid. M.p. 55.0 $56.0{ }^{\circ} \mathrm{C}$ (from ethyl acetate/petroleum ether). ${ }^{1} \mathrm{H}$ NMR $(400 \mathrm{MHz}$, $\left.\mathrm{CDCl}_{3}\right): \delta=1.51\left(\mathrm{~s}, 9 \mathrm{H}, \mathrm{CH}_{3} \mathrm{Boc}\right), 3.72\left(\mathrm{~s}, 3 \mathrm{H}, \mathrm{OCH}_{3}\right), 4.53(\mathrm{~m}$, $2 \mathrm{H}, \mathrm{CH}_{2}$ ), 5.25 (br s, $1 \mathrm{H}, \alpha \mathrm{CH}$ ), 5.57 (br s, $1 \mathrm{H}, \mathrm{NH}$ ), 7.99-8.05 (m, $4 \mathrm{H}, \mathrm{ArH}), 8.12-8.21(\mathrm{~m}, 4 \mathrm{H}, \mathrm{ArH}), 8.37(\mathrm{~d}, J=9.2 \mathrm{~Hz}, 1 \mathrm{H}$, $\mathrm{ArH}) \mathrm{ppm} .{ }^{13} \mathrm{C}$ NMR $\left(100.6 \mathrm{MHz}, \mathrm{CDCl}_{3}\right): \delta=28.30\left[\mathrm{C}\left(\mathrm{CH}_{3}\right)_{3}\right]$, $46.94\left(\mathrm{CH}_{2}\right), 52.71\left(\mathrm{OCH}_{3}\right), 66.14(\alpha \mathrm{CH}), 80.34\left[\mathrm{OC}\left(\mathrm{CH}_{3}\right)_{3}\right]$, $123.13(\mathrm{CH}), 124.69(\mathrm{CH}), 124.78(\mathrm{C}), 125.00(\mathrm{C}), 125.08(\mathrm{CH})$,
$125.14(\mathrm{CH}), 125.89(\mathrm{CH}), 127.21(\mathrm{CH}), 127.28(\mathrm{CH}), 127.40$ $(\mathrm{CH}), 127.75(\mathrm{CH}), 129.20(\mathrm{C}), 130.79(\mathrm{C}), 130.92(\mathrm{C}), 131.25$ (C), 132.43 (C), $155.21(\mathrm{C}=\mathrm{O}), 170.58(\mathrm{C}=\mathrm{O})$. HRMS (TOF): Calcd. for $\mathrm{C}_{25} \mathrm{H}_{27} \mathrm{~N}_{2} \mathrm{O}_{4} 469.19708$; found 469.19653 .

\section{Supplementary Data}

Table SD1. Ratio of emission intensities between excimer and monomer, $\mathrm{I}_{\mathrm{E}} / \mathrm{I}_{\mathrm{M}}$, for the bipyrenylamino acid $\mathbf{4}$ in several solvents (the viscosity of solvents at room temperature is also indicated).

Figure SD1. Plot of $\ln \left(\mathrm{I}_{\mathrm{E}} / \mathrm{I}_{\mathrm{M}}\right)$ versus $\ln \eta$ for the bipyrenylamino acid 4.

Figure SD2. Fitting of the decay curve of the bipyrenylamino acid 4 $\left(\lambda_{\mathrm{em}}=500 \mathrm{~nm}\right)$ in ethanol, as an example.

\section{Acknowledgments}

This work was supported by FEDER through the COMPETE Program and by the Portuguese Foundation for Science and Technology (FCT) in the framework of the Strategic Projects of CFUM [PEst-C/FIS/UI0607/2011 (F-COMP-01-0124-FEDER-022711)] and CQ/UM [PEstC/QUI/UI0686/2011 (FCOMP-01-0124-FEDER-022716)] and through the research project PTDC/QUI/81238/2006 (FCOMP-01-0124-FEDER007467). The NMR spectrometer Bruker Avance II 400 is part of the National NMR Network and was acquired with funds from FCT and FEDER. FCT is also acknowledged for the $\mathrm{PhD}$ grant of G.P. (SFRH/BD/38766/2007).

1. Ross, J.B.A.; Szabo, A.G.; Hogue, C.W.V.; Method Enzymol. 1997, 278, 151-190.

2. Twine, S.M.; Szabo, A.G.; In Methods in Enzymology, I.P. Gerard Marriott (Ed.), Academic Press, 2003; pp 104-127.

3. Katritzky, A.R.; Narindoshvili, T.; Org. Biomol. Chem. 2009, 7, $627-$ 634.

4. Kalyanasundaram, K.; Thomas, J.K.; J. Am. Chem. Soc. 1977, 99, 2039-2044.

5. Winnik, F.M.; Chem. Rev. 1993, 93, 587-614.

6. Egusa, S.; Sisido, M.; Imanishi, Y.; Macromolecules 1985, 18, 882889.

7. Szymanska, A.; Wiczk, W.; Lankiewicz, L.; Amino Acids 2001, 21, 265-270.

8. Alves, I.; Cowell, S.; Lee, Y.S.; Tang, X.J.; Davis, P.; Porreca, F.; Hruby, V.J.; Biochem. Biophys. Res. Commun. 2004, 318, 335-340.

9. Abreu, A.S.; Castanheira, E.M.S.; Ferreira, P.M.T.; Monteiro, L.S.; Pereira, G.; Queiroz, M.-J.R.P.; Eur. J. Org. Chem. 2008, 5697-5703.

10. Pereira, G.; Abreu, A.S.; Castanheira, E.M.S.; Coutinho, P.J.G.; Ferreira, P.M.T.; Queiroz, M.-J.R.P.; Eur. J. Org. Chem. 2009, 39063916.

11. Ferreira, P.M.T.; Maia, H.L.S.; Monteiro, L.S.; Eur. J. Org. Chem. 2003, 2635-2644.

12. Ferreira, P.M.T.; Monteiro, L.S.; Eur. J. Org. Chem. 2006, 3226-3234.

13. Wiessner, A.; Hüttmann, G.; Kühnle, W.; Staerk, H.; J. Phys. Chem. 1995, 99, 14923-14930.

14. Techert S.; Schmatz, S.; Wiessner, A.; Staerk, H.; J. Phys. Chem. A 2000, 104, 5700-5710.

15. Morris, J.V.; Mahaney, M.A.; Huber, J.R.; J. Phys. Chem. 1976, 80, 969-974.

16. Hissler, M.; Harriman, A.; Khatyr, A.; Ziessel, R.; Chem.-Eur. J. 1999, 5, 3366-3381.

17. Valeur, B.; Molecular Fluorescence - Principles and Applications, Wiley-VCH, Weinheim, 2002. 
18. Martinho, J.M.G.; Castanheira, E.M.S.; Reis e Sousa, A.T.; Saghbini, S.; André, J.C.; Winnik, M.A.; Macromolecules 1995, 28, 1167-1171.

19. Castanheira, E.M.S.; Martinho, J.M.G.; Duracher, D.; Charreyre, M.T.; Elaïssari, A.; Pichot, C.; Langmuir 1999, 15, 6712-6717.

20. Dong, D.C.; Winnik, M.A.; Can. J. Chem. 1984, 62, 2560-2565.

21. Chong, P.L.-G.; Thompson T.E.; Biophys. J. 1985, 47, 613-621.

22. Basu, B.J.; Rajam, K.S.; Sens. Actuator B-Chem. 2004, 99, 459-467.

23. Focsaneanu, K.-S.; Scaiano, J.C.; Photochem. Photobiol. Sci. 2005, 4, 817-821.

24. Niko, Y.; Hiroshige, Y.; Kawauchi, S.; Konishi, G.; J. Org. Chem. 2012, 77, 3986-3996 and references therein.

25. Birks, J.B.; In Photophysics of Aromatic Molecules, Wiley, New York, 1970.

26. Andriessen, R.; Boens, N.; Ameloot, M.; De Schryver, F.C.; J. Phys. Chem. 1991, 95, 2047-2058.

27. Lide, D.R. (Ed.); Handbook of Chemistry and Physics, 83th Edition, CRC Press, Boca Raton, 2002.

28. Maçanita, A.L.; Zachariasse, K.A.; J. Phys. Chem. A 2011, 115, 31833195 .
29. Chen, S.; Duhamel, J.; Langmuir 2013, 29, 2821-2834.

30. Melnick, R.L.; Haspel, H.C.; Goldenberg, M.; Greenbaum, L.M.; Weinstein, S.; Biophys. J. 1981, 34, 499-515.

31. Almeida, L.M.; Vaz, W.L.; Zachariasse, K.A.; Madeira, V.M.; Biochemistry 1982, 21, 5972-5977.

32. Kang, S.; Kang, I.G.; Yun, I.; Arch. Pharm. Res. 1997, 20, 1-6.

33. Szajdzinska-Pietek, E.; Wolszczak, M.; Plonka, A.; Schlick, S.; J. Am. Chem. Soc. 1998, 120, 4215-4221.

34. Díaz-Fernández, Y.A.; Rodríguez-Calvo, S.; Pérez-Gramatges, A.; Pallavicini, P.; Patroni, S.; Mangano, C.; J. Colloid Interface Sci. 2007, 313, 638-644.

35. Díaz-Fernández, Y.A.; Mottini, E.; Pasotti, L.; Craparo, E.F.; Giammona, G.; Cavallaro, G.; Pallavicini, P.; Biosens. Bioelectron. 2010, 26, 29-35.

36. Demas, J.N.; Crosby, G.A.; J. Phys. Chem. 1971, 75, 991-1024.

37. Fery-Forgues, S.; Lavabre, D.; J. Chem. Educ. 1999, 76, 1260-1264.

38. Marquardt, D.W.; J. Soc. Ind. Appl. Math. 1963, 11, 431-441.

39. Abreu, A.S.; Silva, N.O.; Ferreira, P.M.T.; Queiroz, M.-J.R.P.; Tetrahedron Lett. 2003, 44, 3377-3379. 